\title{
The Quality Characteristics of Electric Illuminants
}

\author{
Dr. Andriy Andrushko ${ }^{1}$, Dr. Markiyan Hoshko ${ }^{2}$ \\ ${ }^{1}$ Associate Professor, Department of Economics, Lviv National Agrarian University, Ukraine \\ ${ }^{2}$ Associate Professor, Department of Mechanics and Power Engineering, Lviv National Agrarian University, \\ Ukraine
}

\begin{abstract}
Electric illuminants quality characteristics are the objective prerequisite for ensuring of artificial illumination optimal parameters. Since consumers purchase electric illuminants to get enough lighting onto the working surface, poor quality products may not ensure normal conditions both, for work and for everyday living. The article defines, and then investigates the quality characteristics of electric illuminants, available in Ukrainian market. The results show that the quality of electric illuminants, available in the market, does not correspond to consumers' expectations. Such outcomes pose many questions that induce for further research.
\end{abstract}

Keywords: Characteristics, Electric Illuminants, Glow Lamp, Quality, Values.

\section{INTRODUCTION}

The quality of products, delivered to contemporary customers, is one of the "hottest" topics that is being discussed in managerial and economic scientific literature (Jones and George, 2006, p. 303-312; Cronin et al., 2000; Zeithaml, 1988). Indeed, the product quality belongs to those driving forces that determine effective functioning of competitive markets, form sound economic environment, and finally contribute to the overall welfare increase in a country. Despite the fact that the delivery of quality products to customers is considered to be a must in contemporary business world, the problem of poor quality products in the market still persists today. "We all know the importance of delivering a quality product or service. No one tries to do a bad job, and everyone says that they want to provide a quality service. Nonetheless, poor results often show up in the form of unwanted products, non-responsive processes, or unsatisfactory service performance for customers" (Burlton, 2001, p. 193).

An illuminant quality characteristics are the objective prerequisite for ensuring of artificial illumination optimal parameters both, in households and in production facilities. "The ensuring of favourable conditions for visual perception of objects is an important factor of working environment, which contributes to the reduction of industrial injuries and diseases, and to the productivity increase" (Syerikov and Orobinska, 2009, p. 53). The insufficient illumination does not allow workers to perform their tasks efficiently, causes exhaustion and great visual effort (Gajdachuk et al., 2011, p. 21). Thus, the incorrect and insufficient illumination facilitates the injuries danger, decreases productivity and work quality, and finally can lead to substantial worsening of human health.

The aim of this investigation is (1) to clarify the role of electric illuminants quality characteristics in ensuring of artificial illumination optimal parameters, (2) to compare actual illuminants characteristics with those, declared by producers, as well as (3) to establish further research prospects in this direction.

\section{THE QUALITY OF ELECTRIC ILLUMINANTS}

Usually, the quality of a product is associated with consumers' demands and can be defined as the totality of features and characteristics of a product or service that bears on its ability to satisfy stated or implied needs (Johnson and Winchell, 1989, p. 2). "Quality is the degree to which a specific product conforms to a design or specifications" (Gilmore, 1974). The materials that make up the product, the design and engineering of the product, product performance and reliability are all important characteristics of the "quality package" (Collins Dictionary, 2000).

Scientific researchers distinguish between humanistic and mechanistic quality. Humanistic quality involves the subjective response of people to objects and is therefore a highly relativistic phenomenon that differs between judges; mechanistic quality involves an objective aspect or feature of a thing or event (Holbrook and Corfman, 1985, p. 33). Due to the subjectivism of the humanistic quality our investigation will be focused on the mechanistic quality of electric illuminants, which is also called "objective quality". "Objective quality" is the term used to describe the actual technical superiority or excellence of the products (Monroe and Krishnan, 1985), and refers to measurable and verifiable superiority on some predetermined ideal standard or standards (Zeithaml, 1988, p. 4). 
Before starting to analyze the electric illuminants quality characteristics, it is necessary at first, to determine those technical features that define the illuminants quality. As it was already stated in the introduction section, electric illuminants must ensure artificial illumination optimal parameters, to create comfortable working and/or living conditions. Hence, the volume of light, or simply the illuminance, is the main technical characteristic of an illuminant, which reflects its quality. It is vital to emphasize that in real life the illuminance may depend on multiple factors (i. g. altitude of an illuminant over the working surface, colour of ceiling or walls etc.). It is really difficult sometimes to determine the influence of these factors upon the illuminance. However, for our investigation it is important to choose such parameters, that allow to clearly characterize the quality of an illuminant. To do this, we must retrieve some physics.

Illuminance $(E)$ is calculated by the following formula (Kozlovskaya et al., 2011, p. 14):

$$
E=\frac{F}{S}
$$

where, $F$ - the luminous flux onto the surface, $l m$

$S$ - the area of the lighted surface, $m^{2}$

The luminous efficacy $(L E)$ and power $(P)$ determine the luminous flux (Vasylega, 2010, p. 203), that

is:

$$
F=L E \times P
$$

Thus, the illuminance formula may be written as follows:

$$
E=\frac{L F \times P}{S}
$$

According to the formula (3), when the luminous efficacy and the area of the lighted surface are constant, the illuminance direclty depends on power. In other words, the power volume, consumed by an illuminant, directly influences the illuminance. The power consumption can be clearly measured, therefore this parameter may be chosen to characterize the quality of an illuminant. Moreover, producers usually indicate the power volume, consumed by an illuminant, and this sets a good base for comparison.

Since the consumed power directly affects the illuminance level, and may be chosen as the main quality characteristic of electric illuminants, we decided to investigate experimentally the quality of products, available in Ukrainian market. For the preliminary experiment the following electric illuminants were taken: glow lamp "Pila", produced in Poland; glow lamp "Electrum", produced in Vietnam; white lighting luminous tube lamp "Global", produced in China; light-emitting diode lamp "Global", produced in China; mercury tungsten arc lamp "Iskra", produced in Ukraine; quartz-halogen lamp "Electrum", produced in Vietnam; sodium vapor lamps of high and low pressure, produced in Ukraine.

Figure 1 depicts the electric circuit, which was designed for the investigation of illuminants technical characteristics.



Figure 1: The Electric Circuit for the Investigation of Illuminants Technical Characteristics

(TV - autotransformer; HL - the lamp under exanination; A - amperemeter; V - voltmete; Lx - luxmeter)

The preliminary experiments under the nominal voltage $220 \mathrm{~V}$ yielded the results, shown in table 1 . The last column of the table also shows the illuminants power characteristics, declared by producers.

Table 1: Illuminants and Their Power Characteristics

\begin{tabular}{|l|c|c|}
\hline \multicolumn{1}{|c|}{ Illuminants } & $\begin{array}{c}\text { The experiment } \\
\text { results } \\
\text { (power, Watt) }\end{array}$ & $\begin{array}{c}\text { Power characteristics, declared } \\
\text { by producers } \\
\text { (power, Watt) }\end{array}$ \\
\hline Glow lamp «Pila» & 92,4 & 100 \\
Glow lamp «Electrum» & 81,7 & 100 \\
White lighting luminous tube lamp «Global» & 32,45 & 25 \\
Light-emitting diode lamp «Global» & 6,6 & 3 \\
Mercury tungsten arc lamp "Iskra" & 156,2 & 125 \\
Quartz-halogen lamp «Electrum» & 451 & 400 \\
Sodium vapor lamps of low pressure & 451 & 400 \\
Sodium vapor lamps of high pressure & 522 & 500 \\
\hline
\end{tabular}


The preliminary results show that there are discrepancies between the declared and actual technical characteristics of illuminants. This allows us to state the following hypothesis:

$$
\begin{gathered}
\text { The quality of electric illuminants, available in the market, does not correspond to } \\
\text { consumers' expectations. }
\end{gathered}
$$

An appropriate investigation methodology must be developed to verify the stated hypothesis.

\section{METHODOLOGY}

The statistical process control method was chosen to investigate the actual quality parameters of electric illuminants. Due to the fact that the investigation scopes did not allow to take into consideration the entire assortment of illuminants, available in Ukrainian market, the only one group of illuminants, namely the glow lamps with power consumption $100 \mathrm{~W}$, was chosen to investigate the actual quality characteristics of electric illuminants. The own funds of the authors served as the financial base for the investigation. The following glow lamps formed the statistical population: glow lamp "Philips", produced in Poland by the "Philips Lighting", Netherlands; glow lamp "Electrum", produced in Vietnam by the "Rang Dong Light Source and Vacuum Flask" Joint Stock Company, Vietnam; glow lamp "Belsvet", produced in Belorussia by the OAO "Brest Electric Lamps Factory", Belorussia; glow lamp "Iskra" produced in Ukraine by the Joint Stock Company "Iskra", Ukraine; glow lamp "Osram", produced in France by the OSRAM GmBH, Germany; glow lamp "Aro", produced in Ukraine by the Joint Stock Company "Iskra" for "Metro Cash\&Carry Ukraine". For the experiment purity the lamps were purchased at different points of sale, including big trade centers and private entrepreneurs' stores. No more than five lamps of the same producer were purchased at one point of sale.

Twenty samples, each containing five glow lamps, were formed for the investigation. Due to the fact that the investigation purpose was not to compare illuminants quality of different producers, as well as to the fact that some producers are represented in the market only partially, fifteen samples contained the following glow lamps: "Philips", "Osram", "Iskra", "Belsvet" and "Electrum"; the rest five - "Philips", "Osram", "Iskra", "Belsvet" and "Aro" (see Appendix).

The following tasks were to be fulfilled:

1. Using the electric circuit, depicted in the figure 1, to find out the actual characteristics of the illuminants, namely the power (Watt) and illuminance (Lux), and the illuminance per unit of power (Lux/Watt).

2. According to the experimental data, to calculate the average of all sample means ( $\overline{\bar{x}}$ ), and to compare this average with the values, declared by producers. To find out the variations in case of their existence.

3. To calculate control limits for ranges for each sample, to find out the dispertion of power and illuminance values, and causes of quality characteristics variations - natural or assignable.

4. To make conclusions and draw some possible future investigation prospects.

\section{DATA ANALYSIS}

As it was already stated above, twenty samples, each containing five glow lamps, had been formed for the investigation. The experimental results for each sample are shown in the Appendix. Based on experimental data, the sample means and the average $(\overline{\bar{x}})$ of all sample means for power, illuminance and illuminance per unit of power were calculated. The results of calculations are shown in table 2 .

Table 2: The Sample Means and the Average of all Sample Means for Power, Illuminance and

\begin{tabular}{|c|c|c|c|c|c|c|}
\hline \multirow[b]{2}{*}{ Sample } & \multicolumn{3}{|c|}{ The sample means $(\bar{x})$} & \multicolumn{3}{|c|}{ The average of all sample means $(\overline{\bar{x}})$} \\
\hline & Power, W & Illuminance, Lx & $\begin{array}{l}\text { Illuminance per } 1 \mathrm{~W} \\
\text { of power, } \\
\mathrm{Lx} / \mathrm{W}\end{array}$ & Power, W & Illuminance, Lx & $\begin{array}{l}\text { Illuminance per } 1 \mathrm{~W} \\
\text { of power, } \\
\mathrm{Lx} / \mathrm{W}\end{array}$ \\
\hline 1 & 94,82 & 1428,20 & 15,04 & \multirow{8}{*}{94,11} & \multirow{8}{*}{1431,97} & \multirow{8}{*}{15,22} \\
\hline 2 & 95,44 & 1446,60 & 15,14 & & & \\
\hline 3 & 89,76 & 1451,60 & 16,45 & & & \\
\hline 6 & 94,82 & 1411,40 & 14,88 & & & \\
\hline 7 & 94,82 & 1393,20 & 14,67 & & & \\
\hline 8 & 92,88 & 1406,60 & 15,14 & & & \\
\hline 9 & 95,00 & 1428,20 & 15,02 & & & \\
\hline 10 & 92,53 & 1393,00 & 15,05 & & & \\
\hline
\end{tabular}
Illuminance per Unit of Power 


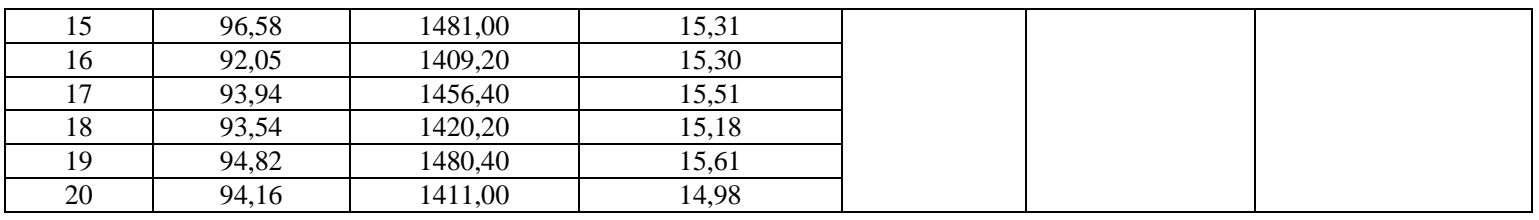

As the table shows, the average of all sample means for power index $-94,11 \mathrm{~W}$ does not correspond to the value, declared by the producers $-100 \mathrm{~W}$. For more detailed analysis it is necessary to calculate control limits for ranges for each sample in order to determine the dispertion of power values. Limits are established that contain \pm 3 standard deviations of the distribution for the average range $\bar{R} .99,7 \%$ of the time, the sample means must fall within \pm 3 standard deviations, if they do not, the values variations are not natural, what means they are caused by production defects. We can set upper and lower control limits for ranges by these formulas:

$$
\begin{aligned}
& U C L_{R}=D_{4} \bar{R} \\
& L C L_{R}=D_{3} \bar{R}
\end{aligned}
$$

where, $U C L_{R}$ - upper control limit for the range

$L C L_{R}$ - lower control limit for the range

$\bar{R}$ - average of the samples $=9,71$.

$D_{4}$ and $D_{3}$ - values from the table of factors for computing control charts limits (assuming that quantity of standard deviations is 3 and confidence level is 99.7\%) (Render et al., 2006, p. 689).

So, the range control limits for power are:

$U C L=2,114 \times 9,71=20,53$

$L C L=0 \times 9,71=0$

Having calculated the range control limits for power we can visually depict the values variations (Fig. 2 ). The horizontal axes shows the numbers of the samples, the vertical axes shows the power values.

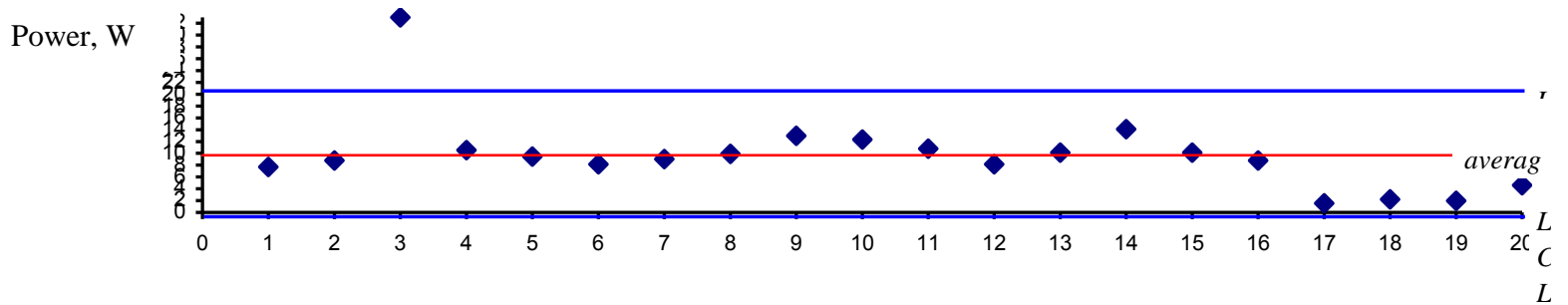

\section{Figure 2: The Range Control Chart for Power Values}

The Fig. 2 shows that the range variance of power values in the sample \#3 is above the upper control limit. Besides, there is a trend towards the lower control limit (samples \#17, \#18, \#19 and \#20). Such a situation means that the process is unstable, and actually confirms the calculated earlier data on power values, none of which corresponded to the values, declared by the producers.

We continue further our analysis and consider the indices of illuminance and illuminance per unit of power, since they are directly dependent on power consumption. Again, we establish control limits for the above mentioned indices, and if a sample mean does not fall within \pm 3 standard deviations, this signals that the process variations are not natural. To set control limits we use the average range and the following formulas:

$$
\begin{aligned}
& U C L_{\bar{x}}=\overline{\bar{x}}+A_{2} \bar{R} \\
& L C L_{\bar{x}}=\overline{\bar{x}}-A_{2} \bar{R}
\end{aligned}
$$

where, $\bar{R}$ - average of the samples

$A_{2}$ - values from the table of factors for computing control charts limits (assuming that quantity of standard deviations is 3 and confidence level is 99.7\%) (Render et al., 2006, p. 689)

$\overline{\bar{x}}$ - mean of the sample means. 
For illuminance $\overline{\bar{x}}=1431,97$, and the average range $\bar{R}=754,4$. So the $U C L$ and $L C L$ for this index are:

$U C L=1431,97+(0,577 \times 754,4)=1867,26$

$L C L=1431,97-(0,577 \times 754,4)=996,68$

For illuminance per $1 \mathrm{~W}$ of power $\overline{\bar{x}}=15,22$, and the average range $\bar{R}=3,57$. So the $U C L$ and $L C L$ for this index are:

$$
\begin{aligned}
& U C L=15,22+(0,577 \times 3,57)=17,28 \\
& L C L=15,22-(0,577 \times 3,57)=13,16
\end{aligned}
$$

Having calculated the control limits for illuminance and illuminance per unit of power, we can visually depict the values variations (Fig. 3 and 4).

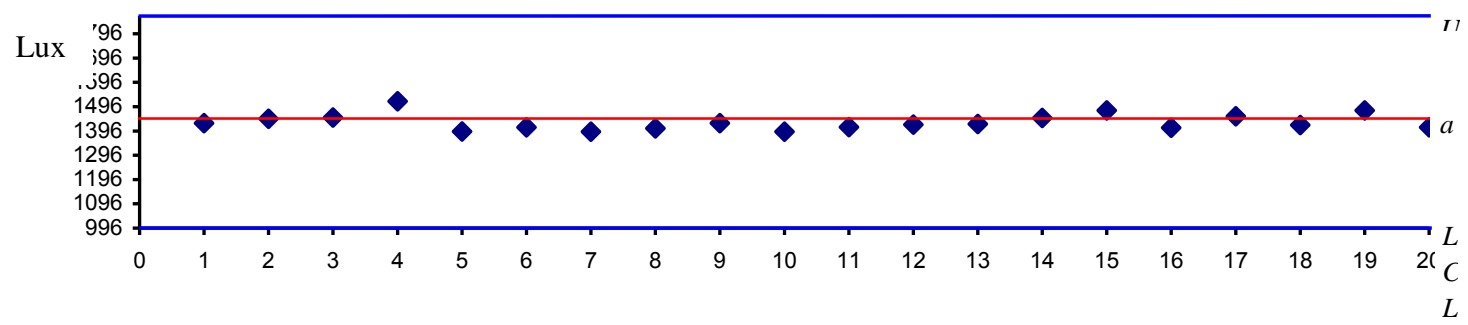

Samples

Figure 3: The Control Chart for Illuminance Values

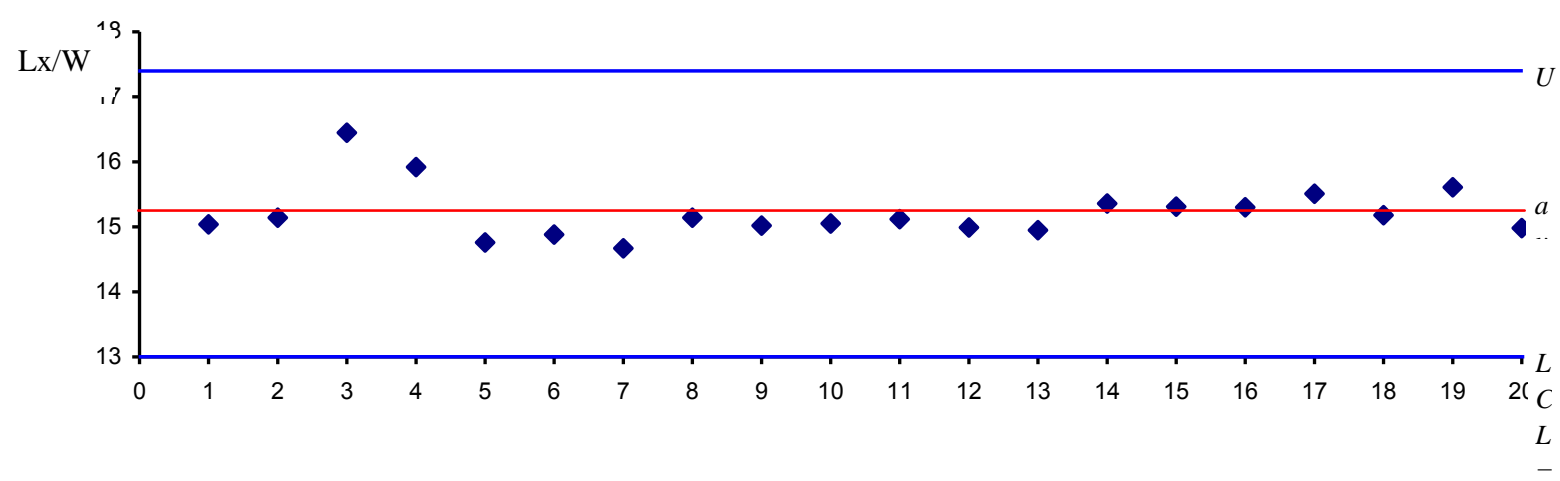

Samples

Figure: 4: The Control Chart for Illuminance per 1W of Power Values

The Figures 3 and 4 show that the sample means of illuminance and illuminance per unit $\mathrm{f}$ power values are within the control limits and generally approach the average value. However, the means of many samples are below the central line. To better understand the process behaviour, it is relevant to build the range control charts for the mentioned above indices. To calculate the range control limits we use formulas (4) and (5).

$U C L$ and $L C L$ for the illuminance range are:

$U C L=2,114 \times 754,4=1594,80$

$L C L=0 \times 754,4=0$

$U C L$ and LCL for the illuminance per unit of power range are:

$U C L=2,114 \times 3,57=7,54$

$L C L=0 \times 3,57=0$

Having calculated the range control limits we can visually depict the values variations (Fig. 5 and 6). 


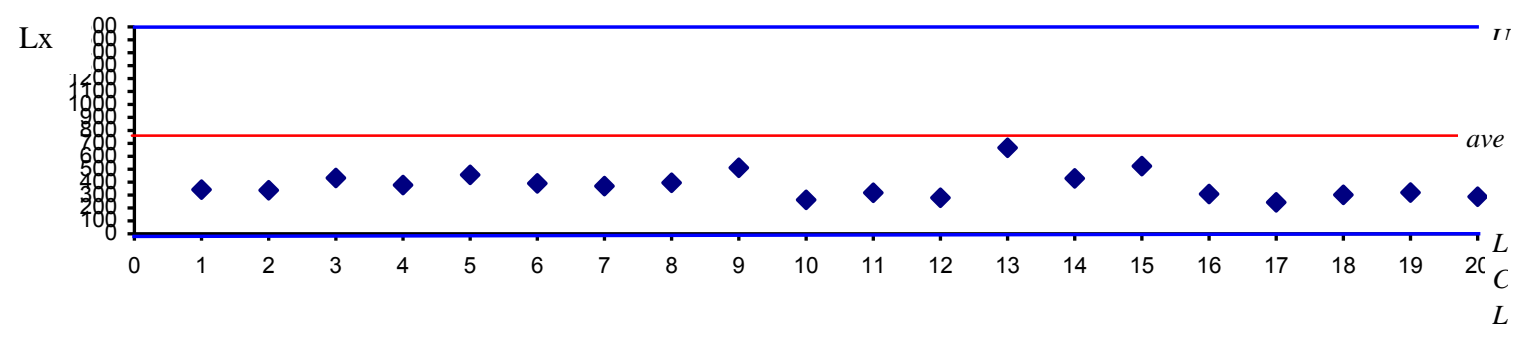

Samples

Figure 5: The Range Control Chart for Illuminance Values

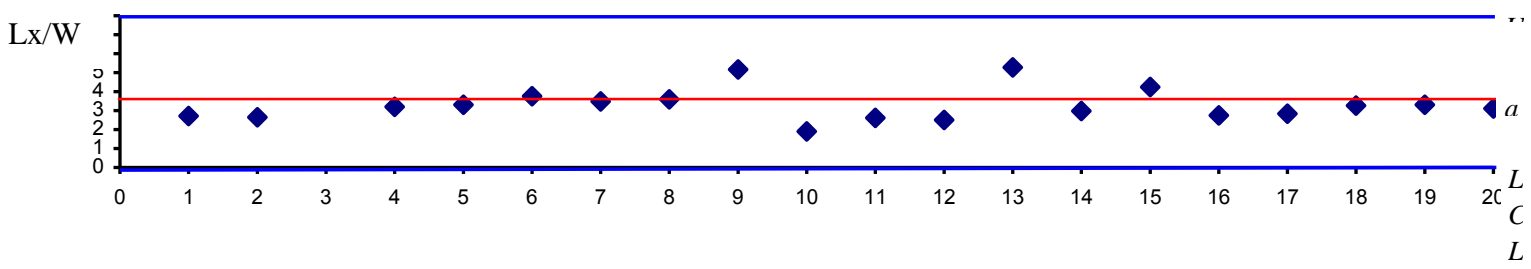

Samples

Figure 6. The Range Control Chart for Illuminance per Unit of Power Values

As the Fig. 5 shows, all the illuminance range values are below the central line, in other words, there is the clear trend towards the lower control limit. This means that illuminance level is lower that expected. This is not surprising considering the fact that the actual power consumption is lower than declared. The range control chart for illuminance per unit of power (Fig. 6) confirms this tendency as well, since the majority of samples build the trend towards the lower control limit.

\section{CONCluSion AND THE Future ReSEARCh Prospects}

The performed calculations allow us to make the conclusion which confirms the stated previously hypothesis: The quality of electric illuminants, available in the market, does not correspond to the consumers' expectations, that is - the actual power indices are lower than those, declared by producers, what directly influences the illuminance level produced by electric lamps. Considering the fact that consumers normally buy electric illuminants with the purpose to get enough lighting onto the working surface, products of such quality will not ensure artificial illumination optimal parameters.

It is necessary to underline that the performed investigation poses many questions that are to be answered. In particular, it would be relevant to define the level of association between quality indices and prices of electric illuminants, since the prices across producers sometimes differ more than twofold. The main question in this case would be: "To what degree do the prices of some electric illuminants correspond to their quality characteristics?".

The performed calculations and revealed trends are also grounds to state that the variations of the electric illuminants quality characteristics are not natural, but assignable, that is caused by production defects.

Considering this statement it would be relevant to clarify the ethical position of separate producers, if they knowingly declare false characteristics of their products, or such a situation exists due to poor production quality control. On the other hand, it would be interesting to investigate the electric illuminants quality characteristics in the markets of other countries, and to find out if the product quality of the same producer differs across the markets in different countries. 
The investigation of possible economic consequences of insufficient ensuring of artificial illumination optimal parameters at production facilities would become a separate direction of scientific research.

\section{REFERENCES}

[1] Jones Gareth R. and George Jennifer M. (2006) Contemporary Menegement, Fourth Edition, McGraw-Hill / Irwin, New York, NY

[2] Cronin Joseph J., Jr., Brady K. Michael and Hult Tomas M. G. (2000), Assessing the Effects of Quality, Value, and Customer Satisfaction on Consumer Behavioral Intentions in Service Environments, Journal of Retailing, Vol. 76, No. 2, pp. $193-218$.

[3] Zeithaml Valarie A. (1988), Consumer Perception of Price, Quality, and Value: A Means-End Model and Synthesis of Evidence, Journal of Marketing, (July) Vol. 52, pp. 2-22.

[4] Burlton Roger (2001), Business Process Management: Profiting from Process, Sam's Publishing, Indiniapolis, Indiana.

[5] Syerikov Y. O. and Orobinska K. Y. (2009), Методика Проектування Системи Штучного Освітлення Виробничого Приміщення Розподільного Пристрою Тягової Підстанції (Projecting Methodology of Artificial Illumination System for Production Premises of a Traction Substation Switching Center), Illumination and Electric Power Engineering, No.4, pp. 53-58.

[6] Gajdachuk I. P., Mykytenko L. I., Danylevych N. S. (2011), Освітлення Робочих Місиь на Підприємствах Легкої Промисловості (Jobsites Illumination at the Light Industry Enterprises), Bulletin of the Kyiv National University of Technologies and Design, No.1, pp. 21-24.

[7] Johnson Ross and Winchell William O., (1989), Production and Quality, Milwaukee, WI: American Society of Quality Control.

[8] Gilmore H. L., (1974), Product Conformance Cost, Quality Progress, June, No. 16.

[9] Collins Dictionary of Economics, (2000), $3^{\text {rd }}$ ed., in C. Pass, B. Lowes, L. Devies (Ed.), HarperCollins Publishers, Glasgow, "Quality", p. 444.

[10] Holbrook, Morris B. and Kim P. Corfman (1985), "Quality and Value in the Consumption Experience: Phaedrus Rides Again," in Perceived Quality, J. Jacoby and J. Olson, eds. Lexington, MA: Lexington Books, 31-57.

[11] Monroe, Kent B. and R. Krishnan (1985), "The Effect of Price on Subjective Product Evaluations" in Perceived Quality, J. Jacoby and J. Olson, eds. Lexington, MA: Lexington Books, 209-32.

[12] Kozlovskaya V. B., Radkevitch V. N., Satsukevitch V. N. (2011), Электрическое Oсвещение (Electric Illumination), Minsk, Publishing House "Technoperpektiva", 543 p.

[13] Vasylega P. О. (2010), Електротехнологічні Установки. Навчальний Посібник (Electrotechnical Installations. Edисаtional Textbook), Sumy, Publishing House "SumDu", 548 p.

[14] Render Barry, Stair Ralph M.,Jr., Hanna Michael E. (2006), Quantitative Analysis for Management, $9^{\text {th }}$ Edition, Pearson Education, Inc., Upper Saddle River, New Jersey.

\section{APPENDIX}

The Statistical Population and the Experiment Data for the Electric Illuminants Quality Investigation

Sample 1

\begin{tabular}{|c|c|c|c|}
\hline Glow Lamp & Power, $(W)$ & Illuminance, $(L x)$ & $\begin{array}{l}\text { Illuminance per } 1 \mathrm{~W} \text { of power, } \\
\mathrm{Lx} / \mathrm{W}\end{array}$ \\
\hline Philips & 93,72 & 1445 & 15,42 \\
\hline Osram & 92,40 & 1258 & 13,61 \\
\hline Belsvet & 93,50 & 1293 & 13,83 \\
\hline Electrum & 100,10 & 1634 & 16,32 \\
\hline Sample mean & 94,82 & 1428,20 & 15,04 \\
\hline
\end{tabular}

Sample 2

\begin{tabular}{|c|c|c|c|}
\hline Glow Lamp & Power, $(W)$ & Illuminance, $(L x)$ & $\begin{array}{l}\text { Illuminance per } 1 \mathrm{~W} \text { of power, } \\
\mathrm{Lx} / \mathrm{W}\end{array}$ \\
\hline Philips & 93,50 & 1402 & 14,99 \\
\hline Osram & 92,40 & 1244 & 13,46 \\
\hline Iskra & 94,38 & 1521 & 16,12 \\
\hline Belsvet & 95,70 & 1485 & 15,52 \\
\hline Electrum & 101,20 & 1581 & 15,62 \\
\hline Sample mean & 95,44 & 1446,60 & 15,14 \\
\hline Sample range & 8,80 & 337 & 2,65 \\
\hline
\end{tabular}

Sample 3

\begin{tabular}{c|ccc}
\hline Glow Lamp & Power, $(W)$ & Illuminance, $($ Lx $)$ & $\begin{array}{c}\text { Illuminance per 1W of power, } \\
\text { Lx/W }\end{array}$ \\
\hline Philips & 92,18 & 1465 & 15,89 \\
Osram & 92,40 & 1171 & 12,67 \\
Iskra & 94,82 & 1564 & 16,49 \\
Belsvet & 68,20 & 1455 & 21,33 \\
Electrum & 101,20 & 1603 & 15,84 \\
\hline Sample mean & 89,76 & 1451,60 & 16,45 \\
Sample range & 33,00 & 432 & 8,66 \\
\hline
\end{tabular}


The Quality Characteristics of Electric Illuminants

Sample 4

\begin{tabular}{|c|c|c|c|}
\hline Glow Lamp & Power, $(W)$ & Illuminance, $(L x)$ & $\begin{array}{l}\text { Illuminance per } 1 \mathrm{~W} \text { of power, } \\
\mathrm{Lx} / \mathrm{W}\end{array}$ \\
\hline Philips & 92,40 & 1443 & 15,62 \\
\hline Osram & 93,50 & 1344 & 14,37 \\
\hline Iskra & 94,60 & 1663 & 17,58 \\
\hline Belsvet & 92,84 & 1421 & 15,31 \\
\hline Electrum & 102,96 & 1721 & 16,72 \\
\hline Sample mean & 95,26 & 1518,40 & 15,92 \\
\hline Sample range & 10,56 & 377 & 3,20 \\
\hline
\end{tabular}

Sample 5

\begin{tabular}{|c|c|c|c|}
\hline Glow Lamp & Power, $(W)$ & Illuminance, $(L x)$ & $\begin{array}{l}\text { Illuminance per } 1 \mathrm{~W} \text { of power, } \\
\mathrm{Lx} / \mathrm{W}\end{array}$ \\
\hline Philips & 92,18 & 1442 & 15,64 \\
\hline Osram & 92,40 & 1198 & 12,97 \\
\hline Iskra & 91,52 & 1446 & 15,80 \\
\hline Belsvet & 93,72 & 1231 & 13,13 \\
\hline Electrum & 101,64 & 1654 & 16,27 \\
\hline Sample mean & 94,29 & 1394,20 & 14,76 \\
\hline Sample range & 9,46 & 456 & 3,31 \\
\hline \multicolumn{4}{|l|}{ Sample 6} \\
\hline Glow Lamp & Power, $(W)$ & Illuminance, $(L x)$ & $\begin{array}{l}\text { Illuminance per } 1 \mathrm{~W} \text { of power, } \\
\mathrm{Lx} / \mathrm{W}\end{array}$ \\
\hline Philips & 91,96 & 1448 & 15,75 \\
\hline Osram & 92,18 & 1185 & 12,86 \\
\hline Iskra & 94,82 & 1575 & 16,61 \\
\hline Belsvet & 95,04 & 1386 & 14,58 \\
\hline Electrum & 100,10 & 1463 & 14,62 \\
\hline Sample mean & 94,82 & 1411,40 & 14,88 \\
\hline Sample range & 8,14 & 390 & 3,76 \\
\hline
\end{tabular}

Sample 7

\begin{tabular}{c|ccc}
\hline Glow Lamp & Power, $(W)$ & Illuminance, $(L x)$ & Illuminance per 1W of power, \\
Lx/W
\end{tabular}

Sample 8

\begin{tabular}{c|ccc}
\hline Glow Lamp & Power, $(W)$ & Illuminance, $(L x)$ & Illuminance per 1W of power, \\
Lx/W
\end{tabular}

Sample 9

\begin{tabular}{|c|c|c|c|}
\hline Glow Lamp & Power, $(W)$ & Illuminance, (Lx) & $\begin{array}{l}\text { Illuminance per } 1 \mathrm{~W} \text { of power, } \\
\mathrm{Lx} / \mathrm{W}\end{array}$ \\
\hline Philips & 92,62 & 1414 & 15,27 \\
\hline Osram & 92,18 & 1120 & 12,15 \\
\hline Iskra & 94,16 & 1631 & 17,32 \\
\hline Belsvet & 93,50 & 1401 & 14,98 \\
\hline Electrum & 102,52 & 1575 & 15,36 \\
\hline Sample mean & 95,00 & 1428,20 & 15,02 \\
\hline Sample range & 9,90 & 511 & 5,17 \\
\hline
\end{tabular}


The Quality Characteristics of Electric Illuminants

Sample 10

\begin{tabular}{|c|c|c|c|}
\hline Glow Lamp & Power, (W) & Illuminance, $(L x)$ & $\begin{array}{l}\text { Illuminance per } 1 \mathrm{~W} \text { of power, } \\
\qquad \mathbf{L x} / \mathbf{W}\end{array}$ \\
\hline Philips & 91,74 & 1330 & 14,50 \\
\hline Osram & 93,50 & 1310 & 14,01 \\
\hline Iskra & 91,74 & 1373 & 14,97 \\
\hline Belsvet & 86,68 & 1379 & 15,91 \\
\hline Electrum & 99,00 & 1573 & 15,89 \\
\hline Sample mean & 92,53 & 1393,00 & 15,05 \\
\hline Sample range & 12,32 & 263 & 1,90 \\
\hline
\end{tabular}

Sample 11

\begin{tabular}{|c|c|c|c|}
\hline Glow Lamp & Power, $(W)$ & Illuminance, $(L x)$ & $\begin{array}{l}\text { Illuminance per } 1 \mathrm{~W} \text { of power, } \\
\mathrm{Lx} / \mathrm{W}\end{array}$ \\
\hline Philips & 92,40 & 1395 & 15,10 \\
\hline Osram & 94,82 & 1275 & 13,45 \\
\hline Iskra & 92,18 & 1463 & 15,87 \\
\hline Belsvet & 88,44 & 1336 & 15,11 \\
\hline Electrum & 99,22 & 1593 & 16,06 \\
\hline Sample mean & 93,41 & 1412,40 & 15,12 \\
\hline Sample range & 10,78 & 318 & 2,61 \\
\hline
\end{tabular}

Sample 12

\begin{tabular}{|c|c|c|c|}
\hline Glow Lamp & Power, $(W)$ & Illuminance, (Lx) & $\begin{array}{l}\text { Illuminance per } 1 \mathrm{~W} \text { of power, } \\
\mathrm{Lx} / \mathrm{W}\end{array}$ \\
\hline Philips & 93,06 & 1431 & 15,38 \\
\hline Osram & 94,60 & 1293 & 13,67 \\
\hline Iskra & 91,96 & 1488 & 16,18 \\
\hline Belsvet & 94,82 & 1328 & 14,01 \\
\hline Electrum & 100,10 & 1572 & 15,70 \\
\hline Sample mean & 94,91 & 1422,40 & 14,99 \\
\hline Sample range & 8,14 & 279 & 2,51 \\
\hline
\end{tabular}

Sample 13

\begin{tabular}{c|ccc}
\hline Glow Lamp & Power, $(W)$ & Illuminance, $($ Lx $)$ & Illuminance per 1W of power, \\
Lx/W & 14,78 \\
Philips & 92,40 & 1366 & 12,58 \\
Osram & 92,62 & 1165 & 15,41 \\
Iskra & 94,38 & 1454 & 14,10 \\
Belsvet & 92,84 & 1309 & 17,86 \\
Electrum & 102,52 & 1831 & 14,95 \\
\hline Sample mean & 94,95 & 1425,00 & 5,28 \\
Sample range & 10,12 & 666 & \\
\hline
\end{tabular}

Sample 14

\begin{tabular}{c|ccc}
\hline Glow Lamp & Power, $(W)$ & Illuminance, $(L x)$ & Illuminance per 1W of power, \\
& Lx/W & 15,46 \\
Philips & 92,62 & 1432 & 14,35 \\
Osram & 93,72 & 1345 & 16,89 \\
Iskra & 95,26 & 1609 & 13,91 \\
Belsvet & 87,56 & 1218 & 16,19 \\
Electrum & 101,64 & 1646 & 15,36 \\
Sample mean & 94,16 & 1450,00 & 2,98 \\
\hline
\end{tabular}

Sample 15

\begin{tabular}{c|ccc}
\hline Glow Lamp & Power, $(W)$ & Illuminance, $(L x)$ & Illuminance per 1W of power, \\
& & 1401 & 15,05 \\
Philips & 93,06 & 1259 & 13,04 \\
Osram & 96,58 & 1398 & 14,78 \\
Iskra & 94,60 & 1564 & 16,38 \\
Belsvet & 95,48 & 1783 & 17,28 \\
Electrum & 103,18 & 1481,00 & 15,31 \\
Sample mean & 96,58 & 524 & 4,24 \\
\hline
\end{tabular}


The Quality Characteristics of Electric Illuminants

Sample 16

\begin{tabular}{|c|c|c|c|}
\hline Glow Lamp & Power, $(W)$ & Illuminance, $(L x)$ & $\begin{array}{l}\text { Illuminance per } 1 \mathrm{~W} \text { of power, } \\
\mathrm{Lx} / \mathrm{W}\end{array}$ \\
\hline Philips & 94,38 & 1430 & 15,15 \\
\hline Osram & 93,06 & 1315 & 14,13 \\
\hline Iskra & 93,94 & 1586 & 16,88 \\
\hline Belsvet & 85,58 & 1278 & 14,93 \\
\hline Aro & 93,28 & 1437 & 15,41 \\
\hline Sample mean & 92,05 & 1409,20 & 15,30 \\
\hline Sample range & 8,80 & 308 & 2,75 \\
\hline
\end{tabular}

Sample 17

\begin{tabular}{c|ccc}
\hline Glow Lamp & Power, $(W)$ & Illuminance, $(L x)$ & Illuminance per 1W of power, \\
Lx/W
\end{tabular}

Sample 18

\begin{tabular}{|c|c|c|c|}
\hline Glow Lamp & Power, (W) & Illuminance, $(L x)$ & $\begin{array}{l}\text { Illuminance per 1W of power, } \\
\mathrm{Lx} / \mathrm{W}\end{array}$ \\
\hline Philips & 92,84 & 1385 & 14,92 \\
\hline Osram & 93,50 & 1263 & 13,51 \\
\hline Iskra & 95,04 & 1452 & 15,28 \\
\hline Belsvet & 93,06 & 1437 & 15,44 \\
\hline Aro & 93,28 & 1564 & 16,77 \\
\hline Sample mean & 93,54 & 1420,20 & 15,18 \\
\hline Sample range & 2,20 & 301 & 3,26 \\
\hline \multicolumn{4}{|l|}{ Sample 19} \\
\hline Glow Lamp & Power, $(W)$ & Illuminance, $(L x)$ & $\begin{array}{l}\text { Illuminance per } 1 \mathrm{~W} \text { of power, } \\
\mathrm{Lx} / \mathrm{W}\end{array}$ \\
\hline Philips & 96,14 & 1413 & 14,70 \\
\hline Osram & 94,16 & 1314 & 13,95 \\
\hline Iskra & 94,16 & 1549 & 16,45 \\
\hline Belsvet & 95,04 & 1493 & 15,71 \\
\hline Aro & 94,60 & 1633 & 17,26 \\
\hline Sample mean & 94,82 & 1480,40 & 15,61 \\
\hline Sample range & 1,98 & 319 & 3,31 \\
\hline \multicolumn{4}{|l|}{ Sample 20} \\
\hline Glow Lamp & Power, $(W)$ & Illuminance, $(L x)$ & $\begin{array}{l}\text { Illuminance per } 1 \mathrm{~W} \text { of power, } \\
\mathrm{Lx} / \mathrm{W}\end{array}$ \\
\hline Philips & 93,72 & 1409 & 15,03 \\
\hline Osram & 91,74 & 1314 & 14,32 \\
\hline Iskra & 95,48 & 1601 & 16,77 \\
\hline Belsvet & 96,36 & 1316 & 13,66 \\
\hline Aro & 93,50 & 1415 & 15,13 \\
\hline Sample mean & 94,16 & 1411,00 & 14,98 \\
\hline Sample range & 4,62 & 287 & 3,11 \\
\hline
\end{tabular}

